The sale of Matriculation examination solutions was repeated, with Messrs. Ryan and Halstead being responsible for duplicating, and Mr. Russell undertaking the work of postage. The Association again expresses thanks to the anonymous people who supplied the solutions.

Mrs. Hutton again occupied the position of Librarian ; members are glad to know that she has recovered from her illness.

Mr. R. L. Harrison and Mr. H.J Russell have shared the duties of Recorder this year.

The magazines of the Associations of teachers of mathematics in U.S.A., France and Germany have been received during the year.

The death occurred in June of Mr. D. K. Picken, former Master of Ormond College, and for many years one of the leading members or the Association. Mr. Picken occupied the position of President for six years, 1938-1944; he addressed the Association on eleven occasions, and was a very enthusiastic member for many years. An appreciation of his work for the Association is appended to this report.

The Secretary again wishes to express his pleasure at the willingness with which members have co-operated during 1956. While this spirit of cheerful service is evident, the activities of the Association are certain to be successful.

F. Roy Manley, Hon. Secretary.

\title{
OBITUARY
}

David Kennedy Picken, who died on 17th June, 1956, was a member of the Mathematical Association for 51 years and a regular contributor to the Gazette. He was a Scotsman, trained in Glasgow and Cambridge, where in 1902 he was sixth wrangler. After graduation he was successively Lecturer in Mathematics at Glasgow University, and Professor at Victoria College, New Zealand. In 1915 he was called to be Master of Ormond College, residential and ancillary teaching institution affiliated with the University of Melbourne. In that position he had wide administrative duties, and the moral responsibilities attaching to the care of more than 100 undergraduates and a leading lay position in the Presbyterian Church. In a sense therefore he ceased to be a professional mathematician. But the things that interested Picken in mathematics were the fundamental principles-the " elements ": their nature, their proper expression, and the proper exposition of the developments stemming from them. On these things he had deep and even passionate convictions, and it seems that these were to some extent linked with his faith regarding the fundamentals of religion and conduct (the comparison of the " infinities " of mathematics and faith would provide such a link); it is understandable therefore that in mathematical thought and teaching he remained active. In the teaching world he had for many years a responsible position on the Board which prescribes " school certificate " syllabuses and recommends courses of study, and he was an influential member of the bodies which deal similarly with studies within the University of Melbourne; but his more intimate care was for the mathematical well-being of the students in his College, and on many of these he had a decisive influence.

To illustrate these generalities : We all know that multiplication is one of the fundamental operations, and that in omitting the sign of multiplication (.) from expressions such as $a . b$ of $2 . f t$ we are departing from our practice concerning the sign + of addition. But for Picken, to omit the multiplication sign was " wrong" notation. This example may be misleading by suggesting that Picken's dominant concern was with what most people would call trivialities, but it does give a fair indication of the flavour of his writing. Examples may be found in the Gazettes over many years; for one of the last see Vol. XXX 
(1946), p. 200. His published books are The Theory of Elementary Trigonometry (Whitcombe and Tombs, 1910), The Number System of Arithmetic and Algebra (Melbourne Univ. Press, 1923), and (with Miss Winifred Waddell) A First Trigonometry (Melbourne, 1919).

In the field of elementary geometry Picken made a remarkable discovery: the unifying concept of the "complete angle". It is explained, and its utility shown, in the first chapter of Forder's Higher Course Geometry, being there called " the cross". Picken's original paper is in Proc. London Math. Soc. [2], 23 (1925), 45-55.

Picken was of course a prominent member of the Mathematical Association of Victoria - which incidentally has this year (1956) celebrated its Jubilee ; from 1938 to 1944 he was its President. His addresses to the Association, on topics such as The Number System, Ratio and Proportion, and The Quantities of Physics are substantially embodied in his contributions to the Gazette.

T. M. C.

\section{MIDLAND JUNIOR MATHEMATICAL SOCIETY}

\section{REPORT FOR THE QUINQUENNIUM 1952-1957}

In October 1952 a group of enthusiastic mathematicians met at King Edward's School, Birmingham, under the chairmanship of Mr. M. A. Porter, to discuss the launching of the above Society. The original aim was to hold meetings at Birmingham University and arrange outings to places of interest for boys and girls in Midland Schools who study advanced mathematics.

Three main meetings were held in the first year. The inaugural speakes in October 1952 was Mr. W. Hope-Jones who lectured on "Some Fun with Probability". In November Mr. G. A. Montgomerie addressed the Society on "Calculating Machines" and brought with him some demonstration models. Four members read papers in March 1953. With the kind co-operation of Prof. T. A. A. Broadbent, an outing to the Royal Nàval College at Greenwhich took place in the Summer.

During the Session 1953-1954 three meetings were held. The visiting speakers were Mr. A. P. Rollett who lectured on " The Series of Fibonacci " (November 1953) and Dr. E. A. Maxwell on "Geometry" (February 1954). Some members' papers were delivered at the May meeting. A social evening was held successfully in January. There were visits to the Aston collection of models in March and to the Mathematical Laboratory at Cambridge in July, when Dr. E. A. Maxwell was our host, entertaining us to lunch at Queens' College.

Over the period 1954-1955, four meetings were held. There was a social evening in January 1955 and an outing to the Royal Aircraft Establishment, Farnborough, in the Summer. Visiting speakers at the meetings were Mr. E. V. Smith on "Statistics" (November 1954), Dr. R. W. H. Small on "Crystallography" and Prof. C. A. Rogers on "Types of Mathematics" (May 1955).

By the end of 1955 the Society had a steady regular attendance at meetings of some 40-50 members who came from the principal Public and Grammar Schools in Birmingham and the Midlands, and from as far afield as Warwick, Bromsgrove, Dudley, Kidderminster and Sutton Coldfield. As the funds were stabilised for the first time it was decided at this stage to hold six main meetings per session : two each term.

Visiting speakers and their subjects were as follows :

Prof. T. A. A. Broadbent_ " George Boole and his Algebra " (October 1955), 